\author{
Joanna Majchrzak \\ Poznan University of Technology \\ e-mail: joanna.majchrzak@put.poznan.pl \\ ORCID: 0000-0001-8742-0283

\section{Ewa Więcek-Janka} \\ Poznan University of Technology \\ e-mail: ewa.wiecek-janka@put.poznan.pl \\ ORCID: 0000-0002-5596-307X
}

\title{
APPLICATION OF GREY SYSTEMS THEORY IN THE ANALYSIS OF RELATIONSHIPS BETWEEN FAMILY ENTERPRISE COMMUNICATION AND THEIR MARKET ATTITUDE
}

\section{ZASTOSOWANIE TEORII SZARYCH SYSTEMÓW W ANALIZIE RELACJI MIĘDZY KOMUNIKACJĄ A POSTAWĄ RYNKOWĄ PRZEDSIĘBIORSTW RODZINNYCH}

DOI: 10.15611/ie.2019.3.03

JEL Classification: L26, M31, D83

\begin{abstract}
Summary: In this paper, the concept of analysing the relationship between family enterprise internal and external communication and the types of its behaviour in market activities is discussed. Family enterprise communication is the characterized and the use of the Internet for marketing communication is presented. Digital communication requires the new competences enabling to combine knowledge of marketing functions and knowledge of instruments and technologies of information communication. The sequence of specified operations, based on Grey Incidence Analysis, for identifying relationships between the degree of concentration on internal or external communication and family enterprise market attitude is designed. The proposed method is tested on twenty family enterprises and the efficacy of the calculation operations is confirmed. The findings facilitate highlighting how the degree of concentration on internal and external communication impact the family enterprise's market position.
\end{abstract}

Keywords: marketing communication, family business, uncertain system, grey relation analysis.

Streszczenie: $\mathrm{W}$ pracy przedstawiona została koncepcja badania relacji między wewnętrzną i zewnętrzną komunikacją przedsiębiorstw rodzinnych a ich postawą rynkową. Dokonano charakterystki komunikacji przedsiębiorstw oraz przedstawiono istotę komunikacji marketingowej z wykorzystaniem Internetu. Komunikacja internetowa wymaga posiadania 
nowych kompetencji łączenia wiedzy z zakresu podstawowych funkcji marketingu i wiedzy o instrumantach i technologii teleinformatycznej. Odwołując się do podstaw metody badania szarych relacji (Grey Relational Analysis), zaprojektowano sekwencję działań w badaniu relacji między poziomem koncentracji na wewnętrznej i zewnętrznej komunikacji a dominującą postawą rynkową przedsiębiorstw. Potwierdzono skuteczność stosowanych w metodzie operacji obliczeniowych. Posługując się opracowaną metodą, można rozpoznać, w jakim stopniu koncentracja na wewnętrznej lub zewnętrznej komunikacji wpływa na określoną postawę rynkową przedsiębiorstw rodzinych.

Słowa kluczowe: komunikacja marketingowa, przedsiębiorstwa rodzinne, systemy niepewne, analiza szarych relacji.

\section{Introduction}

Family enterprises constitute, according to research (Więcek-Janka, 2019; Shanker, Astrachan, 2003), an average of $70 \%$ of enterprises in countries based on a free market economy. The functioning of family enterprises is associated with specific values that allow for the mutual impingement of family and business spheres. Family enterprises' adaptability to a specific environment comprises several essential elements. They are, among others, efficient communication, a positive approach by members of the enterprise environment and strengthening own identity by becoming familiar with the character of local, regional, national and global communities. However, according to research by Rowe, Haynes and Bentley (1993), personal and family-shaped features of family business owners are more effective variables in explaining the amount of income generated by the company than the enterprise's size, although both categories played a significant role. Another study shows the importance of getting to know and shaping the understanding of cultural differences, from subcultures in one's own community to the cultures of geographically distant societies (Cudowska, 1995). Castree (2004) proves that the economic result depends on the perception of "economy" and "culture" as two performative markers. Activities which aim at creating mutual exchange and entering into multilateral interactions outside the local culture become the basis for communication that is focused on seeking international markets. Their task is to organize interpersonal communication connected with the need to go beyond the limits of one's own culture. The main player in the field of communication is the development of competencies that benefit from the achievements of globalization, transformation and integration (WięcekJanka, 2011). Poutziouris (2001) drew attention to the tendency of family businesses to take risk. In his research $(n=240)$, he proved that family businesses adhere to the principles of economic development. He analysed factors that affect venture capital transactions and points to the essence of communication and relations as the key to achieving success.

Communication in family enterprises contributes to the implementation of all other market functions and goals, i.e. marketing research, shaping of a product range, 
enterprise and product promotion, distribution, shaping economic exchange conditions, shaping pro-market enterprise development, competition, supply, sales, trade negotiations, shaping customer relations, integration with other enterprise functions and managing marketing budget (Mantura, 2015, p. 19). In this study, family enterprises communication is defined with reference to its marketing functions, such as, transferring of information adequate to the company's internal and external goals, understanding market participants, their needs and behaviours, influencing the market environment, and stimulation of market participants' behaviours (Majchrzak, Goliński, and Mantura, 2019, p. 7). In the traditional parameter mix $^{1}$ approach, marketing communication is identified as persuasion based on a one-way communication mode (Waterschoot and Van den Bulte 1992). In marketing relationships, marketing communication is related with informing, listening and answering based on interaction and two-way communication forms (Duncan and Moriarty, 1998). Marketing communication activities are directed toward "establishing, developing, and maintaining successful relational exchanges" (Morgan and Hunt, 1994, p. 22). Thus, communication is the precondition for creating the ongoing, intentional, non-accidental relational exchange (Steinhoff, Arli, Weaven, and Kozlenkova, 2019, p. 370] within the company and with the other market entities, such as suppliers, competitors, education entities, science systems, the authorities, local community and political organizations (Majchrzak et al., 2019, p. 439). In an online context, marketing communication is mediated by Internetbased channels. As distinct from offline communication, which rely on human-tohuman relational interactions, in online communication information is exchanged indirectly and mediated by Internet technologies (Yadav and Pavlou, 2014). In these studies, first, family enterprise internal and external communication are distinguished and the use of the Internet for marketing communication is considered. Second, the Grey System Theory method is applied to analyse the relations between the internal and external communication and family enterprise market attitude.

\section{Forms of enterprise market communication}

\subsection{Internal and external communication}

The enterprise's ability to establish and maintain relationships with other entities in the market determines their ability to adapt to dynamically changing environment conditions as well as meeting the enterprises' needs and goals. A special kind of these relationships is the interchangeable relationships within the enterprise's market activities, where the subject of exchange may be, for example, products, services, works, commodities, goods, information, feelings, support, emotions, and image,

1 The marketing parameter mix is the idea of reflecting marketing as a set of elements, which are most often defined as the so-called four Ps of marketing: product, price, promotion and place (McCarthy, 1964). 
etc. (Mantura, 2015). The functioning of the enterprise in a system of interchangeable relationships with other entities makes it possible to adapt and shape the market environment. The enterprise market communication system plays a fundamental role in shaping relationships in the market. Marketing communication is defined as the transmission of information between entities in the market (cf. Mantura, 2012, p. 24).

Internal communication, i.e. communication between the enterprise's organizational units, enables, among other things, the perception of the surrounding market reality from different perspectives and contributes to the so-called synergy in shaping the targeted changes of the enterprise and its environment [Lu, ElMaraghy, Schuh, and Wilhelm, 2007, p. 605). External communication ensures the enterprise's communication with market environment entities as well as the enterprise's partners' understanding of its intentions, capabilities and potential (Andersen, 2001, p. 168). External communication creates conditions for obtaining information about various market environment factors that influence the potential success of the enterprise and its products on the market (Kijewska and Mantura, 2017, p. 133). In the qualitative perspective, market information is represented by the following areas: economic, technical, demographic, cultural, legal, political, controlling, and naturerelated. In the subjective perspective, it is represented by various environment entities, e.g. suppliers, competitors, management authorities, judicial authorities, local community and political organizations. External communication processes are shaped during the direct relationships of the enterprise's members with partners from the environment, i.e. representatives of the supply market, sales market, competition system, power, education and research, and the social system (Morgan and Hunt, 1994, p. 21). Most information appears here in a natural way during the implementation of standard enterprise functions (Stone, Bond, and Blake, 2007, p. 75). Internal communication enables the integration of information which is shaped by input from an enterprise's own human resources. Enterprise employees are perceived as socalled "part-time marketers" (Gummesson, 1987, pp. 16-17). A comprehensive approach to an enterprise's employees' marketing information is expected to lead to the better adjustment of the enterprise to the market environment, create better product offers and plan better marketing activities (Kotler and Keller, 2012, p. 75).

Relationships between the enterprise's marketing communication and, among other things, the trust and commitment between entities are addressed by Morgan and Hunt (1994) and brand value, i.e. perceived quality of the product, loyalty towards the enterprise and its products, brand awareness and brand image by Villarejo-Ramos and Sanchez-Franco (2005). The factors analysed are those that positively influence the enterprise's marketing communication, including ones that contribute to shaping the so-called relationship communication through which relationships that are relevant to entities in the market are established (Finne and Grönroos, 2009). There are also publications that deal with the study of the influence of internal communication on, among other things, employees' identification with 
the enterprise and its reputation on the market (Smidts, Pruyn, and Riel, 2001), job satisfaction and organizational commitment (Zientara and Kuczyński, 2009), and the enterprise's market orientation (Suleiman Awwad and Mohammad Agti, 2011). It has been noted that internal communication in the form of on-the-job training increases a firm's ability to innovate in countries with transition economies (Nazarov and Akhmedjonov, 2012).

In this paper the authors propose the concept of identifying relationships between the enterprise's concentration on a particular form of family enterprise communication, i.e. internal communication or external communication and its dominant bearing on activity in the market. Three types of market positions that may be adopted by a family enterprise in market activities have been singled out:

1) a traditional market attitude (focused on values related to the security of employees, clients, members of the business family);

2) an innovative market attitude (focused on rapid development and gaining competitive advantage);

3) a mixed market attitude (focused on the adaptation to current market requirements).

The next subsection of the article presents the main characteristic of digital communication which is nowadays the inherent form of family enterprises internal and external marketing communication.

\subsection{Digital communication}

Under the influence of the increasing number of Internet users, communication via the Internet has becoming a daily routine. With Internet apps, companies can easily establish relationships with customers and co-operators without the constraints of geographic borders or time zones (Shen, Chiou, Hsiao, Wang, and Li, 2016, p. 2265). The use of the digital media in communication processes facilitate the electronic management of customer relationship and the management of digital customer data (Hudák, Kianičková, and Madleňák, 2017, p. 342). The current tendency in Internet technology is to provide companies with more personalized tools, and emphasis on the changing needs and comfort of customers while accessing information (Semeradova and Vávrová, 2016, p. 278). From a marketing perspective, the Internet means interactivity and the ability to capture cognitive information for forecasting customers' needs, analysing their preferences and delivering personalized products (Hamid and McGrath, 2005, p. 35).

Digital marketing communication (alternative terms are often: online marketing communication, internet marketing communication, or web marketing communication) means the targeted, measurable and interactive communication within a company and with its market environment, using digital technologies (see Todor, 2016, p. 52). The application of such as digital media such as e-mails, podcasts, video, newsletters, social media facilitate creating and maintaining relationships 
with target groups, forwarding companies' messages broadly, and increasing product awareness [Shen et al., 2016, p. 2265].

Therefore, digital communication is a growing phenomenon. The effective use of digital communication by family enterprises requires both knowledge of marketing functions and knowledge of instruments and technologies of information com-munication (Szymczak, 2019, pp. 58-59). The selected advantages and disadvantages of digital marketing communication are presented in Table 1.

Table 1. Advantages and disadvantages of digital communication

\begin{tabular}{|c|c|}
\hline Advantages of digital communication & Disadvantages of digital communication \\
\hline $\begin{array}{l}\text { - Cost efficiency compared to traditional mass } \\
\text { media marketing communication. } \\
\text { - Interactivity, the online users can choose when } \\
\text { to initiate contact and for how long. } \\
\text { - Empowering effect, Internet communication } \\
\text { can extend market reach and operational } \\
\text { efficiency, especially of small and medium } \\
\text { enterprises. } \\
\text { - Infinite audience, which means both to reach } \\
\text { the entire world, but also to tailor a digital } \\
\text { communication to reach a local audience. } \\
\text { - Duration, online information is permanently } \\
\text { available. } \\
\text { - Dialogue, with and among users, online } \\
\text { marketing communication allows } \\
\text { collaboration between users. } \\
\text { - Easily measurable, digital technologies allow } \\
\text { the measuring of marketing communication } \\
\text { impact much easier than traditional marketing. } \\
\text { - Digital marketing communication is adjusted } \\
\text { to customer preferences, behaviour and profile } \\
\text { created based on digital customer data. }\end{array}$ & $\begin{array}{l}\text { - The copyright, the information transferred } \\
\text { in Internet marketing communication can be } \\
\text { easily copied by competitor. } \\
\text { - Difficulties may appear in case of slow } \\
\text { Internet connections. } \\
\text { - Digital communication does not allow the user } \\
\text { to involve all the senses during the exchange } \\
\text { of information. } \\
\text { - The lack of cognitive information for building } \\
\text { strong, long-term relations, incomplete } \\
\text { information about the co-operator's individual } \\
\text { characteristics. } \\
\text { - Internet marketing communication is not } \\
\text { yet embraced by all people, especially older } \\
\text { ones, still do not trust digital environment, } \\
\text { preferring to use the traditional methods. } \\
\text { - Internet marketing communication is highly } \\
\text { dependent on technology which can be prone } \\
\text { to errors. } \\
\text { - The use of digital media in marketing } \\
\text { communication can take some time to obtain } \\
\text { measurable success. }\end{array}$ \\
\hline
\end{tabular}

Source: own studies based on (Todor, 2016, pp. 52-53).

The comprehensive analysis of the family enterprises marketing communication is the scope of this study. The authors considered the main functions (i.e. the exchange of information for cognition and adaptation to the market environment) and forms (i.e. internal and external) and indicated the growing importance of digital communication. The analysis of the relations between the dominant form of marketing communication in a family enterprise and the declared attitude in market activity is the matter of interest of this study. In the next section the concept of the relations between family enterprise communication and their market attitude analysis based on the Grey Incidence Analysis is proposed. 


\section{Application of the Grey Incidence Analysis}

Acquiring data from family enterprises is hampered by difficult access to full data on such enterprises. The problem concerns the characteristics of research samples, such as response coefficients, enterprise size and age, distribution of power and ownership and general availability of data. The number of returned responses from surveys is often too low (Stamm and Lubiński, 2011) for statistical analyses to be used in a classical way. Family enterprises are usually smaller, and the profit structure is different from non-family enterprises (Westhead and Cowling, 1998). The availability of data on such enterprises is limited, especially in large data sets, where the family category is not distinguished (Bird, Dutta-Roy, Heyl, Allison, Asmar, Folkner, Preston, Atkinson, Edenhofer, Plettemeier, Wohlmuth, Iess, and Tyler, 2002). The majority of family businesses are usually privately owned, which hinders the process of accessing detailed data by national statistical institutes. Sources usually contain only basic information such as the company's contact details or the date of its establishment. Another problem is the fact that business owners and managers are often reluctant to provide confidential information about their enterprise, its organization and the relationship to their family (Winter, Fitzgerald, Heck, Haynes, and Danes, 1998). There are several reasons why family members may not want to participate in basic research activities using surveys or interviews. Owners of family enterprises involved in their management do not usually want to share confidential decision-making processes (Schulze, Lubatkin, Dino, and Bucholtz, 2001). They are reluctant to permit information to be obtained from employees (Ward, 1997) and they protect knowledge about their internal activities related to the competition (Donnelley, 1988). Similar difficulties in obtaining data relate to the values and traditions of business families that avoid negative advertising (Aronoff and Ward, 1997) and prefer not to say anything that might damage their reputation.

Due to the complexity of, and difficulties in, research processes in the field of family entrepreneurship, the use of the method of the Grey System Theory in the analysis of data related to family businesses seems to be justified as such data are often incomplete. The Grey System Theory was introduced relatively recently, in 1982 in China. It was created by Chinese scholar, Professor Deng Julong and presented in the publication "The Control Problems of Grey Systems" (Liu and Lin, 2006, p. 2). The Research methods and procedures developed within the framework of the Grey System Theory allow for inference based on incomplete information that usually occurs when (Liu, Yang, and Forrest, 2016, p. 5):

- information about system elements (parameters) is incomplete,

- information about the system structure is incomplete,

- information about the system boundaries is incomplete,

- information about the system behaviour is incomplete.

Nowadays this theory is being dynamically developed, which is confirmed by the increase in publications related to its application in economic and social and technical sciences (Cempel, 2014), e.g. in economics (Delcea, 2015; Liu and Wang, 
1996), quality management (Więcek-Janka, Mierzwiak, and Kijewska, 2016; Majchrzak, Goliński, and Mantura, 2019), agriculture (Liu, Dang, Li et al., 1998), medicine (Chen, 1999; Tan, 1997), stock-market predictions (Wu and Chen, 2011), Internet access population forecast (Wu and Chen, 2005), and software cost estimation (Liu and Qiao, 2014). Theoretical and practical research in Grey Systems Theory can relate to diverse branches of science and economic practice. Traditional Grey Systems Methods can be divided into (Liu et al., 2016, pp. 18-26): Grey Incidence Analysis similar to regression models, Grey Forecast Models based on specific differential equations, Grey Clustering Models aimed at grouping the objects, Grey Decision Models similar to multi-criteria decision making methods, and Hybrid Models which combine Grey Systems Theory methods with data analysis methods such as Rough Set Theory or Fuzzy Logic. The place the Grey Systems Theory occupies in the structure of existing methods of uncertainty research is shown in Table 2.

Table 2. Comparison among the four methods of uncertainty research

\begin{tabular}{|l|l|l|l|l|}
\hline \multicolumn{1}{|c|}{$\begin{array}{c}\text { Uncertainty } \\
\text { research }\end{array}$} & \multicolumn{1}{|c|}{ Grey system } & Prob. statistics & \multicolumn{1}{|c|}{ Fuzzy math } & \multicolumn{1}{|c|}{ Rough set } \\
\hline Research objects & Poor information & Stochastics & Cognitive & Boundary \\
\hline Basic set & Grey number set & Cantor set & Fuzzy set & Approximate set \\
\hline Describe method & Possibility func. & Density func. & Membership func. & Upper, lower appr. \\
\hline Procedure & Sequence operator & Frequency & Cut set & Dividing \\
\hline Data requirement & Any distribution & $\begin{array}{l}\text { Known } \\
\text { distribution }\end{array}$ & Known membership & Equivalent rel. \\
\hline Emphasis & Intension & Intension & Extension & Intension \\
\hline Objective & Law of reality & Historical law & Cognitive expression & $\begin{array}{l}\text { Approx. } \\
\text { approaching }\end{array}$ \\
\hline Characteristics & Small data & Large sample & Depend on experience & Information form \\
\hline
\end{tabular}

Source: (Liu et al., 2016, p. 11).

The properties of the Grey Systems Theory in comparison with other data analysis methods do not require an assumption related to the probability distribution of the analysed features. This is a consequence of operating on a small sample in which one allows for the emergence of insufficient and incomplete data.

Grey Incidence Analysis (GIA) is used in solving such problems as: which elements of the system are more important than others, which elements of the system have a greater impact on the future development of the system, which elements contribute to positive changes in the system and should be strengthened, and which elements have a negative impact on the future development of the system and should be controlled (Liu and Lin, 2006, p. 85). In the proposed concept, in order to recognize relationships between certain forms of market communication of the enterprise (i.e. external and internal communication) and the dominant attitude in the market activity of the enterprise (i.e. traditional, innovative or mixed market attitude), 
Grey Incidence Analysis was applied using the degree of greyness $\gamma$ (Liu and Lin, 2006, pp. 93-101; Liu et al., 2016, pp. 72-76). The degree of greyness, $\gamma_{i j}$, between vectors of the system variable characteristics, $Y_{j}$, relating to specific forms of communication, and vectors of the system variable factors, $X_{i}$, referring to distinctive conduct in the market activity of the enterprise, was chosen due to its properties such as (Liu and Lin, 2006, pp. 96-97):

1) the feature of normality, i.e. $0<\gamma_{i j} \leq 1$;

2) $\gamma_{i j}\left(X_{i}-Y_{j}\right) \in(0,1]$, which means that a given factor $X_{i}$ and the $Y_{j}$ system characteristics cannot be absolutely unrelated;

3 ) the feature of totality, which means that the change in the environment of the analysed $X_{i}$ factor and the $Y_{j}$ system characteristics (i.e. the change in other factors belonging to this system) affects the value of the degree of greyness between a given $X_{i}$ factor and the $Y_{j}$ system characteristics;

4) the feature of symmetry, i.e. $\gamma\left(X_{i}, Y_{j}\right)=\gamma\left(X_{j}, Y_{i}\right)$;

$5)$ the feature of closeness, the smaller the difference $\left|y_{j}(k)-x_{i}(k)\right|$ the greater the value $\gamma\left(x_{i}, y_{j}\right)$.

Individual operations leading to the calculation of the degree of greyness $\gamma\left(X_{i}, Y_{j}\right)$ between specific forms of marketing communication and the dominant conduct in the market activity of the enterprise are explained below (Liu and Lin, 2006, p. 98).

Operation 1. Determining the sequence of system variable characteristics, i.e. assessing how much a given enterprise focuses on external communication (with clients, institutions, etc.) and internal communication (with managers, employees, family members, etc.) that take the form of system behaviour observation vectors, such as:

$$
\begin{aligned}
& Y_{1}=\left[y_{1}(1), y_{1}(2), \ldots, y_{1}(n)\right], \\
& Y_{2}=\left[y_{2}(1), y_{2}(2), \ldots, y_{2}(n)\right] .
\end{aligned}
$$

Here, $Y_{1}$ - vector of variable values of the assessment of the degree of concentration on external communication, $Y_{2}$ - vector of variable values of the assessment of the degree of concentration on internal communication, $k=1,2, \ldots, n$, and $k$-assessment made by a given family enterprise, $n$ - size of the research sample.

Operation 2. Determining the sequence of system variable factors, i.e. assessing a traditional market position in a given enterprise (i.e. one which is set on values related to the security of employees, clients, business family members), an innovative market position (i.e. focused on rapid development and gaining competitive advantage) or a mixed market position (i.e. geared towards adaptation to current market requirements) that take the form of system behaviour observation vectors, such as:

$$
\begin{aligned}
& X_{1}=\left[x_{1}(1), x_{1}(2), \ldots, x_{1}(n)\right], \\
& X_{2}=\left[x_{2}(1), x_{2}(2), \ldots, x_{2}(n)\right], \\
& X_{3}=\left[x_{3}(1), x_{3}(2), \ldots, x_{3}(n)\right] .
\end{aligned}
$$


Here, $X_{1}$ - vector of variable values of the assessment of the degree of dominance of a traditional market position, $X_{2}$ - vector of variable values of the assessment of the degree of dominance of an innovative market position, $X_{3}$ - vector of variable values of the assessment of the degree of dominance of a mixed market position, $k=1,2, \ldots, n$, and $k$-assessment made by a family enterprise, $n$ - size of the research sample.

Operation 3. Transformation of observation vectors of the $X_{i}, Y_{j}$ system behaviour relative to the average image operator, which relates data of system behaviour observations to their average value (Liu, Lin, 2006, p. 89):

$$
\begin{gathered}
X_{i} D_{1}=\left[x_{i}(1) d_{1}, x_{i}(2) d_{1}, \ldots, x_{i}(n) d_{1}\right], \\
x_{i}(k) d_{1}=\frac{x_{i}(k)}{\bar{X}_{l}}, \bar{X}_{i}=\frac{1}{n} \sum_{i=1}^{n} x_{i}(k), \\
Y_{i} D_{1}=\left[y_{i}(1) d_{1}, y_{i}(2) d_{1}, \ldots, y_{i}(n) d_{1}\right], \\
y_{i}(k) d_{1}=\frac{y_{i}(k)}{\bar{Y}_{l}}, \bar{Y}_{i}=\frac{1}{n} \sum_{i=1}^{n} y_{i}(k) .
\end{gathered}
$$

Here, $k$ - assessment made by a given family enterprise, $n$ - size of the research sample.

Operation 4. Calculation of differences between individual variables of the $Y_{1} D_{1}$, $Y_{2} D_{1}$ characteristics sequence and $X_{1} D_{1}, X_{2} D_{1}, X_{3} D_{1}$ system factors:

$$
\begin{gathered}
\Delta_{i}(k)=\left|y_{i}(k) d_{1}-x_{i}(k) d_{1}\right|, \\
\Delta_{i}=\left(\Delta_{i}(1), \Delta_{i}(2), \ldots, \Delta_{i}(n)\right), i=0,1, \ldots, m, m=3 .
\end{gathered}
$$

Here, $m$ - number of system factors considered in the study.

Operation 5. Finding the maximum and minimum difference between individual variables of the $Y_{1} D_{1}, Y_{2} D_{1}$ characteristics sequence and the $X_{1} D_{1}, X_{2} D_{1}, X_{3} D_{1}$ system factors:

$$
\begin{aligned}
M & =\max _{i} \max _{k} \Delta_{i}(k), \\
m & =\min _{i} \min _{k} \Delta_{i}(k) .
\end{aligned}
$$

Operation 6. Calculation of the level of closeness between individual variables of the $Y_{1} D_{1}, Y_{2} D_{1}$ characteristics sequence and the $X_{1} D_{1}, X_{2} D_{1}, X_{3} D_{1}$ system factors:

$$
y_{i j}(k)=\frac{m+\zeta M}{\Delta_{i}(k)+\zeta M} .
$$

Here, $\zeta$ - distinguishing coefficient of the importance of the largest and smallest difference between particular variables of characteristics sequence and system factors. Assuming the equal importance of the smallest and greatest difference 
between individual variables of characteristics sequence and system factors, the distinguishing coefficient takes on the value $\zeta=0.5$ (Liu and Lin, 2006, pp. 97-100).

Operation 7. Calculation of the value of the degree of greyness, $\gamma_{i j}$, between vectors of the system characteristics variables, $Y_{j}$, and vectors of the system variable factors $X_{i}$ :

$$
y_{i j}=\frac{1}{n} \sum_{i=1}^{n} y_{i j}(k), i=0,1, \ldots, m .
$$

The values of the calculated degree of greyness, $\gamma_{i j}$, between vectors of the system of variable characteristics, $Y_{j}$, relating to specific forms of communication, and vectors of the system variable factors, $X_{i}$, referring to distinctive positions in the market activity of the enterprise, determine the strength of these relationships. The greater the value of the degree of greyness, $\gamma_{i j}$, the greater the strength of the relationships between the studied characteristics and system factors.

The next part of the work presents the results of applying the proposed concept and its empirical verification in terms of the effectiveness of the specified operations. The strength of the relationships between internal and external communication of twenty family enterprises and their conduct in market activity was analysed.

\section{Results of Grey Incidence Analysis application}

The application of the proposed concept for analysing the relationships between family enterprise internal and external communication and its bearing on market activity involved twenty family enterprises. The selected family enterprises satisfy such conditions as: at least two people from the family are professionally involved in the enterprise market activities and the familial character of the enterprise is recognized by the management. The sample included four enterprises with fewer than 10 years of market experience, five enterprises in the range of 11 to 20 years, two enterprises in the range of 21 to 30 years, seven enterprises in the range of 31 to 40 years and two enterprises with more than 41 years of experience. The surveyed enterprises were of the following profiles: production $(n=3)$, trade $(n=3)$, service $(n=2)$, production-service $(n=2)$, production-trade $(n=2)$, trade-service $(n=1)$ and production-trade-service $(n=7)$. The research was carried out using the Computer Assisted Telephone Interview (CATI) method. The representatives of the family enterprises evaluated the following issues (on a five-point scale):

1) to what extent a traditional market position based on security-related values is applied in the enterprise,

2) to what extent the enterprise adopts an innovative market position focused on rapid development and building a competitive advantage,

3 ) to what extent the enterprise uses a mixed market position. 
The respondents were also asked to assess the level of managers' and owners' focus on internal and external communication. The data obtained were used to verify the effectiveness of the proposed concept of analysing the relation between the internal and external communication and market position. The application of the proposed operations facilitates the understanding of how the level of the managers' and owner's focus on internal and external communication is related with a family enterprise's market attitude. Thus, the change in enterprise market attitude, e.g. an increase in its innovativeness, might be achieved by the improvements of its internal or external communication. The results of calculations of individual stages of the GIA method between specific forms of communication and the dominant attitude in the market activity of the enterprise are presented below.

Result 1. Specific sequences of system variable characteristics:

$$
\begin{aligned}
& Y_{1}=[4,4,5,5,5,4,5,4,5,5,4,3,4,5,5,4,4,4,4,4], \\
& Y_{2}=[5,5,3,3,4,5,5,5,4,3,4,4,5,3,4,3,5,5,2,5] .
\end{aligned}
$$

Here, $Y_{1}$ - vector of variable values of the degree of concentration on external communication, $Y_{2}$ vector of variable values of the degree of concentration on internal communication.

Result 2. Specific sequences of system variable factors:

$$
\begin{aligned}
& X_{1}=[4,5,2,3,2,4,2,5,3,2,3,5,5,2,4,3,4,5,2,5], \\
& X_{2}=[2,3,4,5,6,3,5,4,5,5,4,3,4,5,4,4,3,3,5,3], \\
& X_{3}=[5,5,4,5,3,5,3,5,4,4,5,4,4,5,5,5,5,4,5,4] .
\end{aligned}
$$

Here, $X_{1}$ - vector of variable values of the assessment of the degree of dominance of a traditional market position, $X_{2}$ - vector of variable values of the assessment of the degree of dominance of an innovative market position, $X_{3}$ - vector of variable values of the assessment of the degree of dominance of a mixed market position.

Result 3. Transformation of observation vectors of the $X_{i}, Y_{j}$ system behaviour relative to the average image:

$$
\begin{gathered}
Y_{1} D_{1}=[0.92,0.92,1.15,1.15,1.15,0.92,1.15,0.92,1.15,1.15,0.92,0.69,0.92, \\
1.15,1.15,0.92,0.92,0.92,0.92,0.92], \\
Y_{2} D_{1}=[1.22,1.22,0.73,0.73,0.98,1.22,1.22,1.22,0.98,0.73,0.98,0.98,1.22, \\
0.73,0.98,0.73,1.22,1.22,0.49,1.22], \\
X_{1} D_{1}=[1.14,1.43,0.57,0.86,0.57,1.14,0.57,1.43,0.86,0.57,0.86,1.43,1.43, \\
0.57,1.14,0.86,1.14,1.43,0.57,1.43], \\
X_{2} D_{1}=[0.50,0.75,1.25,1.25,1.25,0.75,1.25,1.00,1.25,1.25,1.00,0.75,1.00, \\
1.25,1.00,1.00,0.75,0.75,1.25,0.75] \\
X_{3} D_{1}=[1.12,1.12,0.90,1.12,0.67,1.12,0.67,1.12,0.90,0.90,1.12,0.90,0.90, \\
1.12,1.12,1.12,1.12,0.90,1.12,0.90]
\end{gathered}
$$


Here, $Y D_{1}$ - transformed observation vector of system variable characteristics, $X D_{1}$ - transformed observation vector of system variable factors.

Result 4.1. Calculation of differences between individual variables of the $Y_{1} D_{1}$ characteristic sequence and the $X_{1} D_{1}, X_{2} D_{1}, X_{3} D_{1}$ system factors:

$$
\begin{gathered}
Y_{1}: \Delta_{1}=(0.22,0.51,0.58,0.29,0.58,0.22,0.58,0.51,0.29,0.58,0.06,0.74,0.51, \\
0.58,0.01,0.06,0.22,0.51,0.35,0.51), \\
Y_{1}: \Delta_{2}=(0.42,0.17,0.10,0.10,0.10,0.17,0.10,0.08,0.10,0.10,0.08,0.06,0.08, \\
0.10,0.15,0.08,0.17,0.17,0.33,0.17), \\
Y_{1}: \Delta_{3}=(0.20,0.20,0.25,0.03,0.48,0.20,0.48,0.20,0.25,0.25,0.20,0.21,0.02, \\
0.03,0.03,0.20,0.20,0.02,0.20,0.02) .
\end{gathered}
$$

Result 4.2. Calculated differences between individual variables of the $Y_{2} D_{1}$ characteristic sequence and the $X_{1} D_{1}, X_{2} D_{1}, X_{3} D_{1}$ system factors:

$$
\begin{gathered}
Y_{2}: \Delta_{1}=(0.08,0.21,0.16,0.13,0.40,0.08,0.65,0.21,0.12,0.16,0.12,0.45,0.21, \\
0.16,0.17,0.13,0.08,0.21,0.08,0.21), \\
Y_{2}: \Delta_{2}=(0.72,0.47,0.52,0.52,0.27,0.47,0.03,0.22,0.27,0.52,0.02,0.23,0.22, \\
0.52,0.02,0.27,0.47,0.47,0.76,0.47), \\
Y_{2}: \Delta_{3}=(0.10,0.10,0.17,0.39,0.30,0.10,0.55,0.10,0.08,0.17,0.15,0.08,0.32, \\
0.39,0.15,0.39,0.10,0.32,0.64,0.32) .
\end{gathered}
$$

Result 5.1. Finding the maximum and minimum difference between individual variables of the $Y_{1} D_{1}$ characteristic sequence and the $X_{1} D_{1}, X_{2} D_{1}, X_{3} D_{1}$ system factors:

$$
\begin{aligned}
& M=0.739, \\
& m=0.007 .
\end{aligned}
$$

Result 5.2. Finding the maximum and minimum difference between individual variables of the $Y_{2} D_{1}$ characteristic sequence and the $X_{1} D_{1}, X_{2} D_{1}, X_{3} D_{1}$ system factors:

$$
\begin{aligned}
M & =0.762, \\
m & =0.024 .
\end{aligned}
$$

Result 6.1. The calculated level of closeness between individual variables of the $Y_{1}$ characteristic sequence and the $X_{1}, X_{2}, X_{3}$ system factors (see Appendix 1).

Result 6.2. The calculated level of closeness between individual variables of the $Y_{2}$ characteristic sequence and the $X_{1}, X_{2}, X_{3}$ system factors (see Appendix 2).

Result 7. The calculated value of the degree of greyness, $\gamma_{i j}$, between vectors of the $Y_{j}$ system variable characteristics relating to specific forms of communication, and vectors of variable factors of the $X_{i}$ system referring to distinctive conduct in the market activity of the enterprise.

The validity of the developed concept to assess the effectiveness of examining the relation between the level of managers' and owners' focus on internal and external communication and the extent to which a traditional, innovative or mixed market 
Table 3. The degree of grey relation, $\gamma_{i j}$, between forms of communication distinctive to market attitude

\begin{tabular}{|l|c|c|c|}
\hline The degree of grey relation & $X_{1}$ & $X_{2}$ & $X_{3}$ \\
\hline$Y_{1}$ & $\gamma_{11}=0.538$ & $\gamma_{21}=0.752$ & $\gamma_{31}=0.718$ \\
\hline$Y_{2}$ & $\gamma_{12}=0.691$ & $\gamma_{22}=0.556$ & $\gamma_{32}=0.652$ \\
\hline
\end{tabular}

* $X_{1}$ - the degree of dominance of a traditional market position, $X_{2}$ - the degree of dominance of an innovative market position, $X_{3}$ - the degree of dominance of a mixed market position, $Y_{1}$ - the degree of concentration on external communication, $Y_{2}$-the degree of concentration on internal communication.

Source: own studies.

position is applied in the enterprise has been confirmed. Furthermore, the results obtained indicate that the grey relation, $\gamma_{i j}$, between the degree of concentration on external over internal communication assumes the highest value for the degree of dominance of an innovative and mixed market position, and the lowest value for traditional conduct in the market activity of family enterprises.

This means that changes in the degree of concentration on external communication will have the greatest impact on changes in the degree of dominance of an innovative market attitude (and vice versa). The grey relation, $\gamma_{i j}$, between the degree of concentration on internal over external communication assumes the highest value for the degree of dominance of traditional and mixed market position, and the lowest value for innovative conduct in the market activity of family enterprises. This means that changes in the degree of concentration on internal communication will have the greatest impact on changes in the degree of dominance of a traditional market attitude (and vice versa). It follows then that there is a high level of relationship between external marketing communication and an innovative market attitude and between internal marketing communication and a traditional market attitude. The results obtained may indicate that in order to strengthen an innovative market position, one should consider the need to improve forms of external communication. Internal communication and its quality also have an impact on an innovative market position $\left(\gamma_{22}=0.556\right)$, but not as much as external communication $\left(\gamma_{21}=0.752\right)$. In order to strengthen a traditional market position, the need to improve forms of internal communication must be considered because it shows a high level of closeness to the dominance of a traditional market position $\left(\gamma_{12}=0.691\right)$. Of all the examined relations, external communication has the smallest degree of relation to a traditional market position $\left(\gamma_{11}=0.538\right)$.

\section{Conclusion and outlook}

The concept of analysis of the relationships between family enterprise communication and their market attitude has been proposed in this paper. The sequence of operations was designed based on the Grey Incidence Analysis method. The effectiveness of 


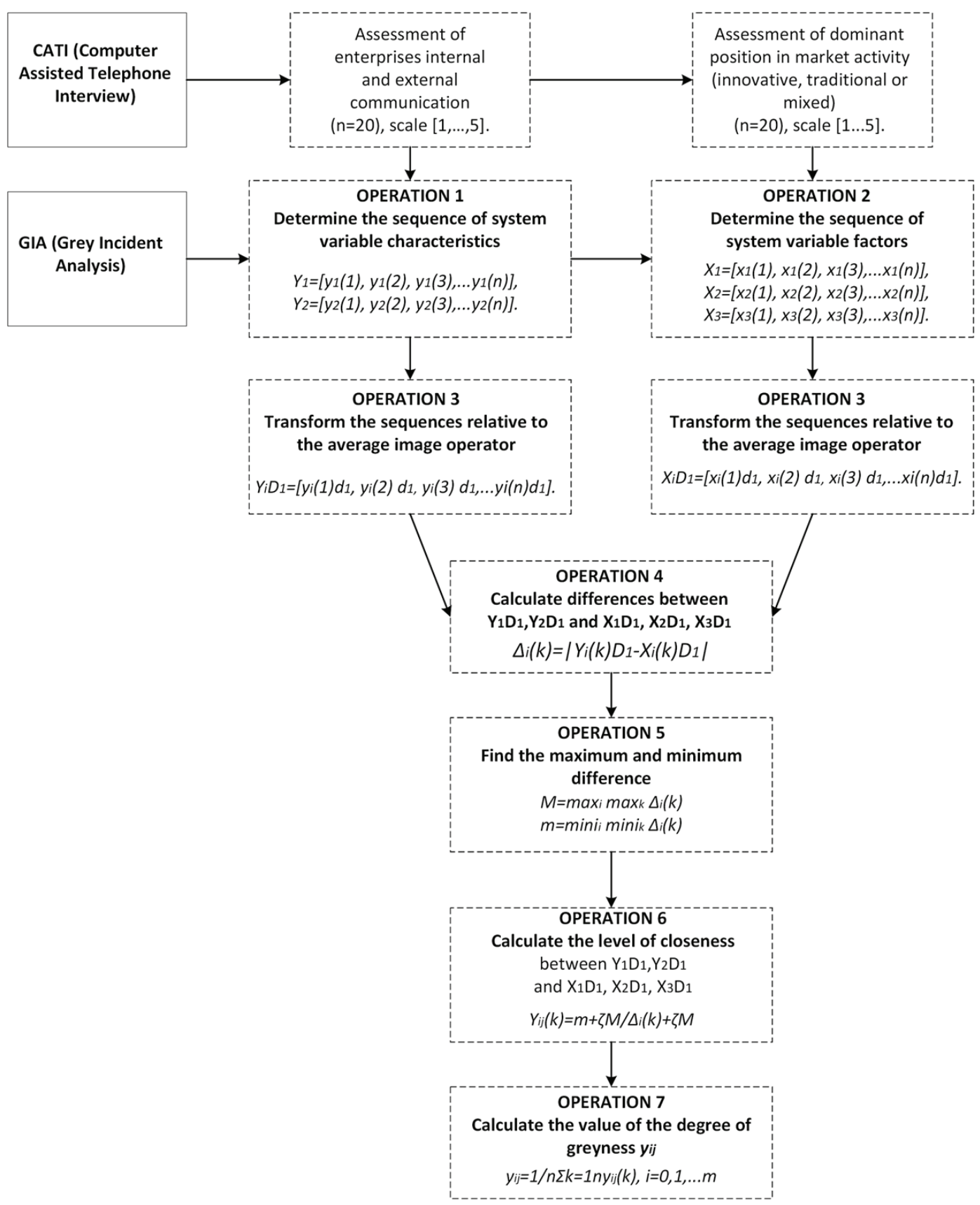

Fig. 1. The course of the research process using GIA

Source: own elaboration. 
this method was empirically tested. The degree of concentration on external communication and on internal communication, and the dominant attitude in the market activity of the enterprise was then empirically assessed. The studies involved twenty families. The research was carried out using the CATI method. The course of this research process is shown in Figure 1. The application of the proposed concept facilitates recognising the impact of the family enterprise's internal or external communication on the its market attitude. Furthermore, the results obtained from twenty companies show the high impact of family enterprise external communication on an innovative position and the high impact of family enterprise internal communication on a traditional position in the market activity of family enterprises. The recognised relations indicated that in order to strengthen an innovative position, the external forms of communication should be improved, and, in order to strengthen a traditional position, the internal forms of communication should be improved. The aim of future research is, first, to apply the mathematical modelling and optimisation function to identify the recommended actions to improve internal or external communication in order to impact the preferred position in the enterprise's market activities. Second, to design IT software supporting computational activities and visualizations of the obtained results.

\section{References}

Andersen, H. P. (2001). Relationship development and marketing communication: An integrative model. Journal of Business \& Industrial Marketing, 16(3), 167-183.

Aronoff, C. E., and Ward, J. L. (1997). Preparing your family business for strategic change. Family Business Leadership Series, 9. Marietta, GA: Business Owner Resources.

Bird, M. K., Dutta-Roy, R., Hey, M., Allison, M., Asmar, S. W., Folkner, W. M., Preston, R. A., Atkinson, D. H., Edenhofer, P., Plettemeier, D., Wohlmuth, R., Iess, L., and Tyler, G. L. (2002). The Huygens Doppler Wind Experiment: Titan winds derived from probe radio frequency measurements. Space Sci. Rev., (104), 613-640.

Castree, N. (2004). Economy and culture are dead! Long live economy and culture! Progress in Human Geography, 28(2), 204-226.

Cempel, C. (2014). Teoria szarych systemów - nowa metodologia analizy i oceny złożonych systemów. Przegląd możliwości. Zeszyty Naukowe Politechniki Poznańskiej. Organizacja i Zarzqdzanie, (64), 9-20.

Chen, K. X. (1999). The epistemology of grey medical analysis (PhD Dissertation). Wuhan: Huazhong University of Science and Technology.

Cudowska, A. (1995). Dialog kultur. Edukacja i Dialog, (10), 11-12.

Delcea, C. (2015). Grey systems theory in economics - a historical applications review. Grey Systems: Theory and Application, 5(2), 263-276.

Donnelley, R. G. (1988). The family business. Family Business Review, 1(4), 335-454.

Duncan, T., and Moriarty, S. E. (1998). A communication-based marketing model for managing relationships. Journal of Marketing, 56(2), 1-13.

Finne, Å., and Grönroos, Ch. (2009). Rethinking marketing communication: From integrated marketing communication to relationship communication. Journal of Marketing Communications, 15(2-3), 179-195. 
Gummesson, E. (1987). The new marketing - developing long-term interactive relationships. Long Range Planning, 20(4), 10-20.

Hamid, N. R. A., and McGrath, M. G. (2005). The diffusion of internet interactivity on retail web sites: A customer relationship model. Communications of the IIMA, 5(2), 4, 35-46.

Hudák, M., Kianičková, E., and Madleňák, R. (2017). The importance of e-mail marketing in e-commerce. Procedia Engineering, (192), 342-347.

Kijewska, J., and Mantura, W. (2017). Istota komunikacji marketingowej i promocji oraz koncepcja klasyfikacji form komunikacji marketingowej przedsiębiorstwa. Handel Wewnętrzny, 6(63), 132-141.

Kotler, P., and Keller, K. L. (2012). Marketing Management (14th Edition). NY: Pearson Education Limited.

Liu, J., and Qiao, J. -Z. (2014). A grey rough set model for evaluation and selection of software cost estimation methods. Grey Systems: Theory and Application, 4(1), 3-12.

Liu, S. F., Dang, Y. G., and Li, B. J. et al. (1998). Computational analysis on the periodic contribution of technological advances in Henan Province. Journal of Henan Agricultural University, 32(3), 203-207.

Liu, S., and Lin, Y. (2006). Grey Information Theory and Practical Application. London: Springer.

Liu, S., Yang, Y., and Forrest, J. (2016). Grey Data Analysis: Methods, Models and Applications. Springer.

Liu, X. Q., and Wang, Z. M. (1996). Grey Econometric Models and Applications. Jinan: Yellow River Press.

Lu, S. Y., ElMaraghy, W., Schuh, G., and Wilhelm, R. A. (2007). A scientific foundation of collaborative engineering. CIRP Annals-Manufacturing Technology, 56(2), 605-634.

Majchrzak, J., Chuda, A., Kalemba, A., and Weber, G. W. (2019). The concept of contradiction finding and classification in the field of marketing communication quality management. In R. Benmoussa, R. De Guio, S. Dubois, S. Koziołek (Eds.), New Opportunities for Innovation Breakthroughs for Developing Countries and Emerging Economies (pp. 438-457). Cham: Springer.

Majchrzak, J., Goliński, M., and Mantura, W. (2019), Cent Eur J Oper Res. https://doi.org/10.1007/ s10100-019-00635-y, 1-24.

Mantura, W. (2012). Comparative analysis of the category of quality information. In M. Goliński, M. Szafrański (Eds.) Integrated support system for access to information in urban space with use of GPS and GIS systems (pp. 7-30). Poznan: Publishing House of Poznań University of Technology.

Mantura, W. (2015). Rozważania o współczesnych problemach marketingu. Zeszyty Naukowe Uniwersytetu Szczecińskiego. Studia i Prace Wydziału Nauk Ekonomicznych i Zarzqdzania, 39(2), 11-23.

McCarthy, E. J. (1964). Basic Marketing. IL: Richard D. Irwin.

Morgan, R. M., and Hunt, S. D. (1994). The commitment-trust theory of relationship marketing. Journal of Marketing, 58(3), 20-38.

Nazarov, Z., and Akhmedjonov, A. (2012). Education, on-the-job training and innovation in transition economies. Eastern European Economics, 50(6), 28-56.

Poutziouris, P. Z. (2001). The views of family companies on venture capital: Empirical evidence from the UK small to medium-size enterprising economy. Family Business Review, 14(3), 277-291.

Rowe, B. R., Haynes, G. W., and Bentley, M. T. (1993). Economic outcomes in family-owned homebased businesses. Family Business Review, 6(4), 383-396.

Schulze, W., Lubatkin, M., Dino, R. N., and Bucholtz, A. K. (2001). Agency relationships in family firms: Theory and evidence. Organization Science, 12(2), 99-116.

Semeradova, T., and Vávrová, J. N. (2016). Using a systemic approach to assess Internet marketing communication within the hospitality industry. Tourism Management, (20), 276-289.

Shanker, M. C., and Astrachan, J. H. (2003). Myths and realities: family businesses' contribution to the US economy - a framework for assessing family business statistics. Family Business Review, 9(2), 107-123. 
Shen, G. C. C., Chiou, J. S., Hsiao, C. H., Wang, C. H., and Li, H. (2016). Effective marketing communication via social networking site: The moderating role of the social tie. Journal of Business Research, 69(6), 2265-2270.

Smidts, A., Pruyn, A. T. H., and Riel, C. B. van (2001). The impact of employee communication and perceived external prestige on organizational identification. Academy of Management Journal, 44(5), 1051-1062.

Stamm, I., and Lubiński, Ch. (2011). Crossroads of family business research and firm demography A critical assessment of family business survival rates. Journal of Family Business Strategy, 2(3), 117-127.

Steinhoff, L., Arli, D., Weaven, S., and Kozlenkova, I. V. (2019). Online relationship marketing. Journal of the Academy of Marketing Science, 47(3), 369-393.

Stone, M., Bond, A., and Blake, E. (2007). Marketing bezpośredni i interaktywny. Warszawa: Polskie Wydawnictwo Ekonomiczne.

Suleiman Awwad, M., and Mohammad Agti, D. A. (2011). The impact of internal marketing on commercial banks' market orientation. International Journal of Bank Marketing, 29(4), 308-332.

Szymczak, A. (2019). Will the use of virtual reality lead to a revolution in marketing communication? Marketing of Scientific and Research Organizations, 33(3), 53-69.

Tan, X. R. (1997). Grey medical incidence theory and applications (PhD Dissertation). Wuhan: Huazhong University of Science and Technology.

Todor, R. D. (2016). Blending traditional and digital marketing. Bulletin of the Transilvania University of Brasov. Economic Sciences. V, 9(1), 51-56.

Villarejo-Ramos, A. F., and Sanchez-Franco, M. J. (2005). The impact of marketing communication and price promotion on brand equity. Journal of Brand Management, 12(6), 431-444.

Ward, J. L. (1997). Keeping the family business healthy: How to plan for continuing growth, profitability, and family leadership. Marietta, GA: Business Owner Resources.

Waterschoot, W., Van den Bulte, C. (1992). The 4P classification of the marketing mix revisited. Journal of Marketing, (56), 83-93.

Westhead, P., and Cowling, M. (1998). Family firm research: The need for a methodological rethink. Entrepreneurship and Regional Development, (4), 21-56.

Więcek-Janka, E. (2011). Konflikt międzykulturowy jako forma zaburzonej komunikacji. Marketing i Rynek, (5), 6-15.

Więcek-Janka, E. (2019). Konflikty w zarzqdzaniu przedsiębiorstwami rodzinnymi. Pojęcia, modele, narzędzia. Poznań: Wydawnictwo Politechniki Poznańskiej.

Więcek-Janka, E., Mierzwiak, R., and Kijewska, J. (2016). Competencies' model in the succession process of family firms with the use of grey clustering analysis. The Journal of Grey System, 28(2), $121-131$.

Winter, M., Fitzgerald, M. A., Heck., R. K. Z., Haynes, G. W., and Danes, S. M. (1998). Revisiting the study of family businesses: Methodological challenges, dilemmas, and alternative approaches. Family Business Review, (11), 239-252.

$\mathrm{Wu}, \mathrm{H}$., and Chen, F. (2011). The application of GST to exchange rate prediction in post-crisis era. International Journal of Innovative Management, Information \& Production, 2(2), 83-89.

Wu, W. Y., Chen, S. P. (2005). A prediction method using the grey model GMC(1,n) combined with the grey relational analysis: A case study on Internet access population forecast. Applied Mathematics and Computation, (169), 198-217.

Yadav, M. S., and Pavlou, P. A. (2014). Marketing in computer-mediated environments: Research synthesis and new directions. Journal of Marketing, 78(1), 20-40.

Zientara, P., Kuczyński, G. (2009). Human resources practices and work-related attitudes in Polish public administration. Eastern European Economics, 47(5), 42-60. 


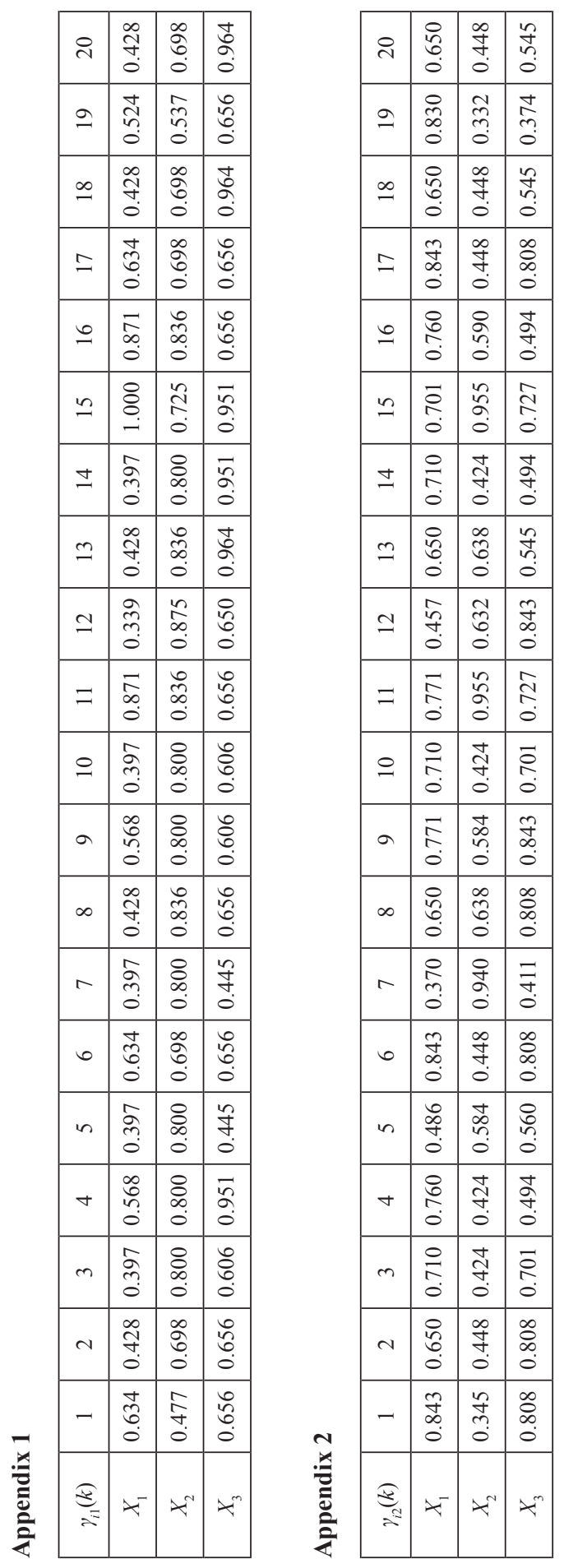

